\title{
An Analysis of Students' Difficulties in Solving Story Based Problems and Its Alternative Solutions
}

\author{
Tika Karlina Rachmawati \\ Mathematics Education Department, UIN Sunan Gunung Djati Bandung \\ Corresponding author: tikakarlina1089@gmail.com
}

\begin{abstract}
This study aims to analyze the students' difficulties of MTs Negeri Surakarta 1 in solving story based problems on the subject of Pythagoras along with its alternative solutions. This is a qualitative descriptive research. This study illustrates the difficulties of students in solving story based problems of the subject of Pythagoras. Research subjects in this study is composed of three students of class IX with each capable of high, medium and low. The data collection was condducted using the test method and the method of interview. The results of this study indicate that low-ability students have difficulty in determining the direction of wind direction, understand the intent of the language that is understood about the story, the difficulty in making a mathematical model as well as difficulties in the calculation. Difficulties experienced by the students with medium capability are determining the drawing of wind direction, understanding the intent of the language that is understood about the story, and making a mathematical model. While the bigh-ability students have no significant problems in understanding a story about the subject of Pythagoras, they just forgot to add \pm sign in the answers, and the unit of length in the final calculation. However, the unit length was written in the final conclusions.
\end{abstract}

Keywords: students' difficulties, Pythagoras, story based problems, alternative solutions

\section{Introduction}

Problems in learning is at the core of the problems of education and teaching for learning as the main activity in education. All efforts have been made by teachers for students to learn because learning activities of students will further develop. The development of students' learning does not always run smoothly and deliver the expected results. There are times when students have difficulties in learning. For educators, helping students to overcome learning difficulties is a very difficult task.

According to Abdurrahman (2012: 1) the difficulty of learning in a translation of the English term is "learning disabilities". The translation is really not appropriate for the word learning which means learning and disability means inability, so the translation is actually a learning disability. The term learning disability is used because it is felt more optimistic. Larning difficulty is a disorder in one or more of the basic psychological processes that include the use of language understanding and speech or writing. The disorder may present difficulties in listening, thinking, speaking, reading, writing, spelling 
or counting. There are several sources or factors suspected as the main cause of students' learning difficulties. The source can come from within the students themselves or from outside the students. Of the student may be caused by biological and psychological factors. While from the outside of the students can be sourced from the family, the environment, friends, and community.

One of the students' difficulties is completing story problems, one of them is about the story based problem of Pytahgoras. Pythagoras was a Greek mathematician and a philosopher who lived in 569-475 BC. As a mathematician, he revealed that the square of the length of the hypotenuse of a right triangle is equal to the square of the length of the other sides (Agus, 2007: 92).

Based on some interviews with teachers of mathematics in class VIII at MTs Negeri Surakarta 1, many students have difficulty in solving story based problems on the subject of Pythagoras. This is evident in the average math test results on the topic of Pythagoras was 56.79. The difficulties appear to be concerned with teaching requires students to make a mathematical model without giving the steps in advance that must be taken. Resolving about the story is not an easy job because the students are trained completing story problems systematically.

To be able to identify the difficulties experienced by students in solving this story based problems of Pythagoras, one of which is to provide a test of the material to the students. Students' errors on their works of the problems that can become one of the clues to find out the difficulties faced by students in understanding the topic of Pythagoras. According to Rahardjo (2016), mathematical ability of students to the material Pythagoras was still low. Students can not apply the concepts learned earlier with the concepts included in Pythagoras so they found difficulties in solving problems. Students have difficulty in understanding the problem because students are still confused and have not been able to make sense of sentences presented. In addition to the material students forget the Pythagorean Theorem. Students also confused in selecting a concept that should be used in solving the problem. On the other hand, Priyanto and Trapsilasiwi (2015) suggested the errors made by the students in solving the story is reading errors was about $43 \%$, the error of understanding was about $46 \%$, errors of transformation was about $49 \%$, an error in the calculation of $55 \%$ as well as errors in drawing conclusion was $61 \%$.

Based on the description above, the author tries to analyze the difficulties of mathematics learning, especially in solving story problems on the topic of Pythagoras. Based on the background described, the problem formulation of this study as follows.

a. Any difficulties experienced by students in completing the story about Pythagoras?

b. How workaround student difficulties in completing the story about Pythagoras?

\section{Research Method}

This is a qualitative descriptive research. The feature of descriptive qualitative study is to make a picture of a situation or event. This study illustrates the difficulties of students in solving the subject of the story based problems of Pythagoras. The subjects taken in this study were 3 students of class IX MTs Negeri Surakarta 1, with each capable of low, medium, and high. Categories are based on the ability of Final Examination Semester (UAS) class VIII semesters 2 and the recommendation of teachers of mathematics. 
Table 1. The Research Subjects

\begin{tabular}{cccc}
\hline No. & Initial & Ability Categories & NE Score \\
\hline 1 & A & Low & 55 \\
2 & B & Middle & 76 \\
3 & C & High & 91 \\
\hline
\end{tabular}

The data in this study were the students' difficulties in completing the subject matter of the story based problems of Pythagoras. The data collection technique used in this study are the test method and the method of interview. The test method is two stories on the subject matter of Pythagoras, while the method of interviews in the form of researchers asking questions is not structured on the students' answers on the test method. Researchers do not use specific guidance interview in conducting interviews with students. This interview method used to obtain a clear picture of the student's difficulties in working on a story about the topic of Pythagoras.

\section{Results And Discussions} as follows.

Two story based problems on the topic of Pythagoras were designed for this study

1. A ship is sailing westward as far as 120 kilometers, then it is continued sailing to the north as far as 90 kilometers. Determine the shortest distance of the ship from the starting point.

2. The area of a rectangle is same as the perimeter of a square with $60 \mathrm{~cm}$ length of its sides. Given the length of the rectangle as $24 \mathrm{~cm}$, determine the diagonal of its rectangle.

\section{Answer of Subject A}

Answer number 1 by the subject A can be seen in Figure 1 .

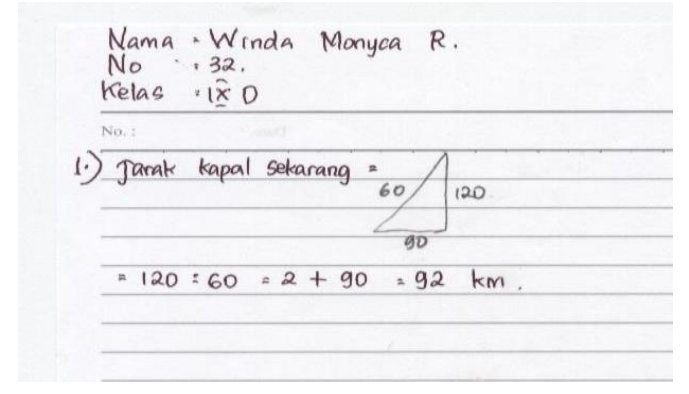

Figure 1. The Answer of Problem Number One by Subject A

Difficulties experienced by students is that students can not understand the purpose and objective of the questions using the form of images, resulting in a lack of understanding of the Pythagorean formula. In addition, students experienced difficulties in applying the formula so it can not resolve the matter in accordance with the existing 
answers. This following transcript is the results of interviews about the answers number one on the subject of A. $\begin{array}{lll}\text { Researcher } & : & \text { "What do you think about question number 1?" } \\ \text { Subject A } & : & \text { "It's hard mam..." } \\ \text { Researcher } & : & \text { "Which one?" } \\ \text { Subject A } & : & \text { "I forgot mam..." } \\ \text { Researcher } \quad: \quad \text { "You used to be taught by the teacher, weren't you?" } \\ \text { Subject A } \quad: \quad \text { "Yes mam, but now I forgot." } \\ \text { Researcher } \quad: \quad \text { "Do you understand what does this problem mean to?" } \\ \text { Subject A } \quad: \quad \text { "Little bit mam.." } \\ \text { Researcher } \quad \text { : } \quad \text { direction in a picture?" }\end{array}$

Subject A : "I do mam..."

Researcher : "Based on the picture, where's my northern side?"

Subject A : "On the downside mm..."

Researcher : "Really? If you see the map, which one is the northern side?"

Subject A : "On the upside mam.."

Researcher : "But you said on the downside?"

Subject A : "Eh right mam...I forgot mam...(smiling)"

Researcher : "Since you already know it, now sketch the wind direction by yourself."

Subject A : "(she was drawing the wind direction on a paper, and she show it to the interviewer)

This is the picture mam."

Researcher : "Okay, now read the problem"

Subject A : "(she's reading question number 1 by scratching her head)"

Researcher : "When you've done reading, the ship sailing to the west, so it sails in which direction? Right or left?"

Subject A : "Left side mam..."(she's drawing on a paper)

Researcher : "Right, then the ship continues sailing to the north, so which direction on the picture?" 


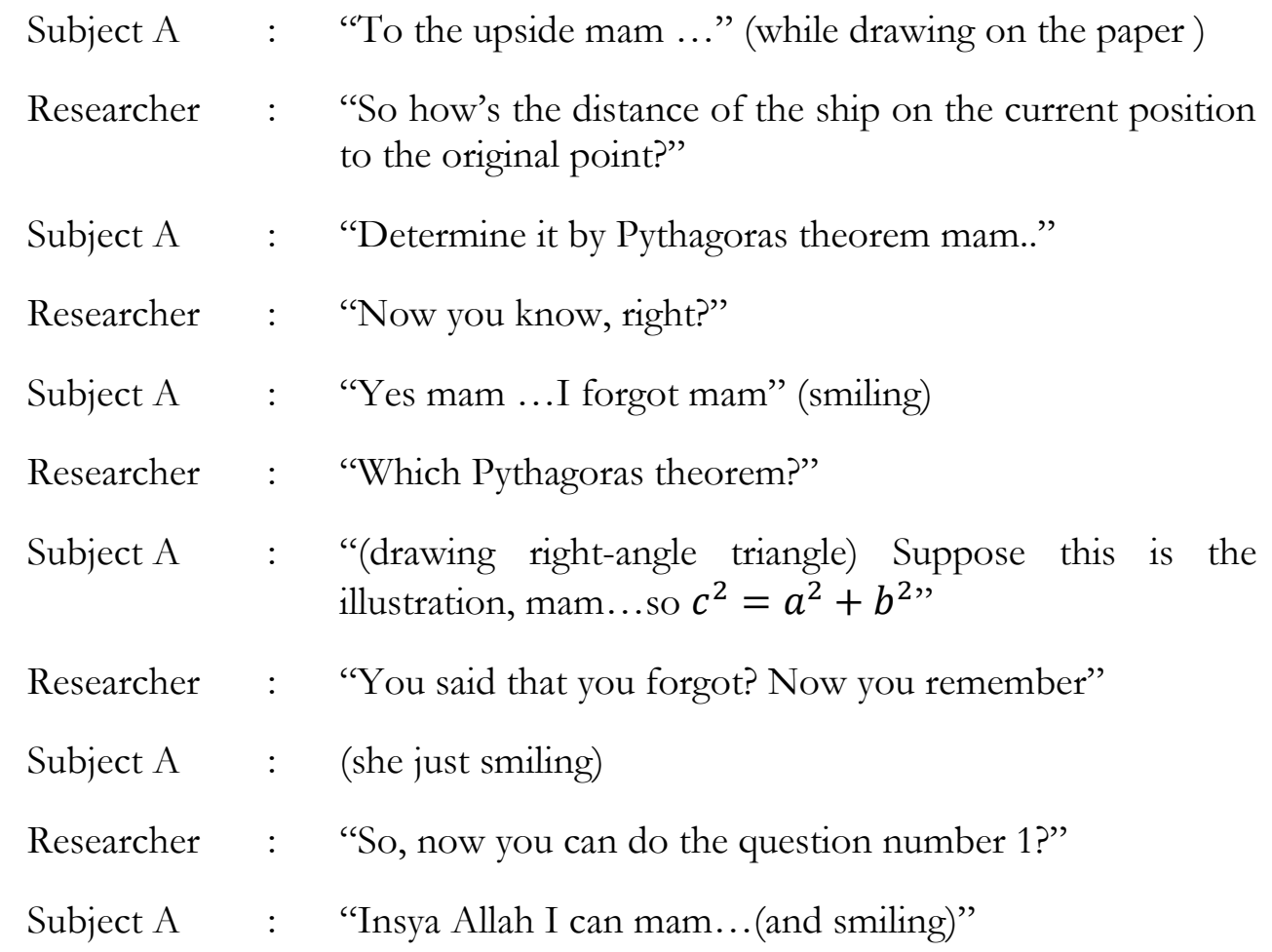

From the excerpts of the interview above, students' difficulties in determining the direction of the wind, that is where the west, east, north, and south in the image. In addition, students have not been able to apply the formula of Pytahgoras in this matter, even though the students had memorized the formula of Pytahgoras. Answer No. 2 by Subject A can be seen in Figure 2.

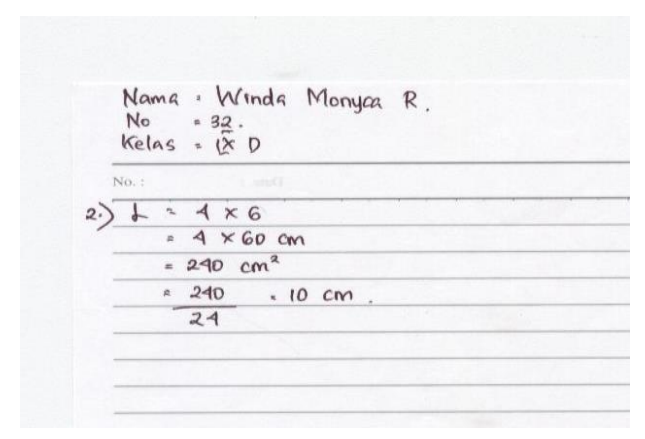

Figure 2. The Answer of Problem Number Two by Subject A

Student answers incorrectly, it seems that students do not understand about changing the word problems into mathematical models. Lack of understanding of the material of plane also make students find difficulties in solving number 2. Results of interviews to Question 2 as follows.
Researcher : "For question number 2, why do you answer $\mathrm{L}=4$ x 60?"
Subject A : "Here mam...the area of a rectangle is the same as its circumstance is $4 \mathrm{x}$ the length side, so $4 \times 60$, which means the area of rectangle is 4 x 60 mam..."




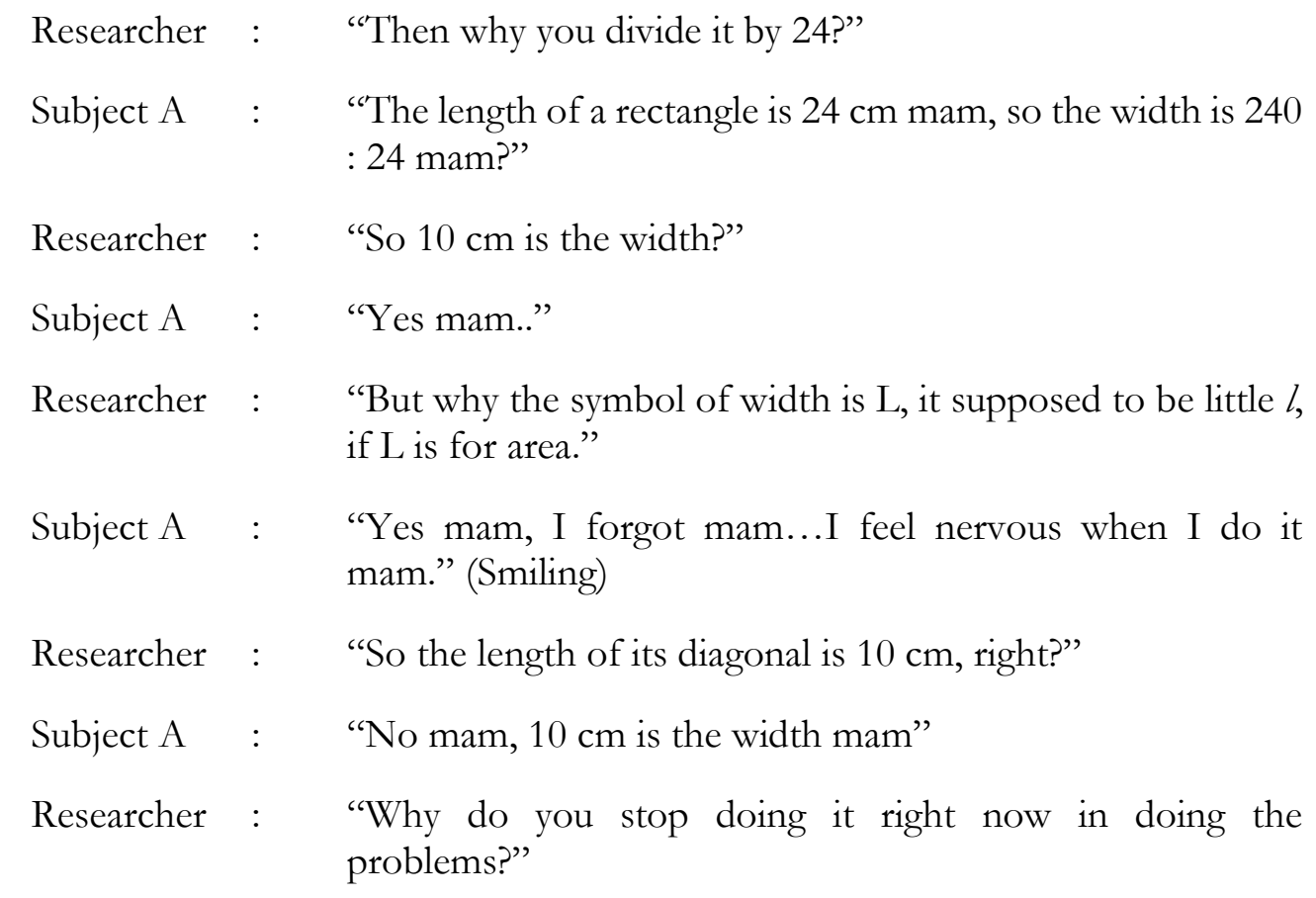

Subject A : "Oh right mam, I still make some mistakes in doing it"

From the interview above, the student can not understand the intent of the question. The student actually know about the formula to find the square circumference and area of a rectangle, but students can not understand the question. While the results of the written test, students made a mistake in determining the direction of the wind before using the Pythagorean formula. After the interviews, the students do not understand the west, east, north, and south in the image. Students also had difficulty in putting the index numbers on the corresponding picture about the intent and purpose. That is what students experience work on the problems of confusion.

In addition, students also do not understand about changing the word problems into mathematical models. Some of the difficulties experienced by students in creating a mathematical model, namely the lack of understanding of the basic form of the formula Pytahgoras, lack of understanding of symbols in mathematics, causing an error, a lack of understanding of the material previously because of problems Pythagoras complex. Students have difficulty understanding the language, such as the lack of students 'understanding of the language problem, especially the language of mathematics, students have difficulty determining the purpose and objective matter, students' difficulties in dealing with problems of Pythagoras complex specifically the application of Pythagoras in the wake others eg Flat square and the square long. As noted Budiyono (2008) the kinds of mistakes made by students in a math problem that is a misconception, include (1) an error determining theorem or formula to address the problem, (2) the use of formula or theorem by students are not in accordance with the conditions prerequisite entry into force the formula. 


\section{Answer of Subject B}

Answer number 1 by the subject B can be seen in Figure 3 .

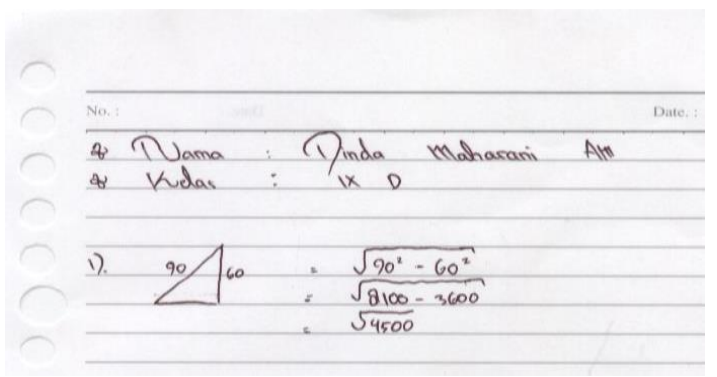

Figure 3. The Answer of Problem Number One by Subject B

It seems like students are able to understand the intent of the story about this number 1, it's just that the students do not understand about the wind direction so that the placement of the distance on this matter to be wrong. Students seem to already know about the Pythagorean formula. Here are the results of interviews about question number 1:

Researcher : "For question number 1, how do you answer that way?"

Subject B : "A ship sails to the west which means the opposite of west is east, so from the west to the east is $120 \mathrm{~km} . "$

Researcher : "Then why did you answer $60 \mathrm{~km}$ ?"

Subject B : "(while he drew a wind direction) This is the figure of wind direction, right? Then it goes $120 \mathrm{~km}$ to the west, if we take from the middle position, then it will be $60 \mathrm{~km}$ mam."

Researcher : "Wait...in which direction on the map if we go to the west? (while pointed on the picture)"

Subject B : "The upside, mam..(still confused)"

Researcher : "Wait...look at the map, the upside represents which wind direction?"

Subject B : "North mam.."

Researcher : 'Then how come do you answer the west is on the upside, Din?"

Subject B : "He...he....(smiling) yes mam, I did wrong..."

Researcher : "Okay, which direction to the west and to the north?"

Subject B : "To the west means to the left with $120 \mathrm{~km}$ long mam. (while drawing)" 
Researcher : "Then it continues to which direction?"
Subject B $\quad$ "To the north means going to $90 \mathrm{~km}$ long."
Researcher : "To determine the distance of the current position to the
original position will be the same as finding which side?"
Subject B : "(pointing the picture) so we must determine the hypotenuse
mam. (smiling)"

Based on the above excerpts of the interview, the student is still confused in the drawing of the wind direction and determine which way is west, east, north, south. Students also can not put the known distance to the direction of the ship running. Actually, students are already familiar with the Pythagorean formula, only the placement direction is not correct, causing errors in counting.

Answer No. 2 by Subject B can be seen in Figure 4.

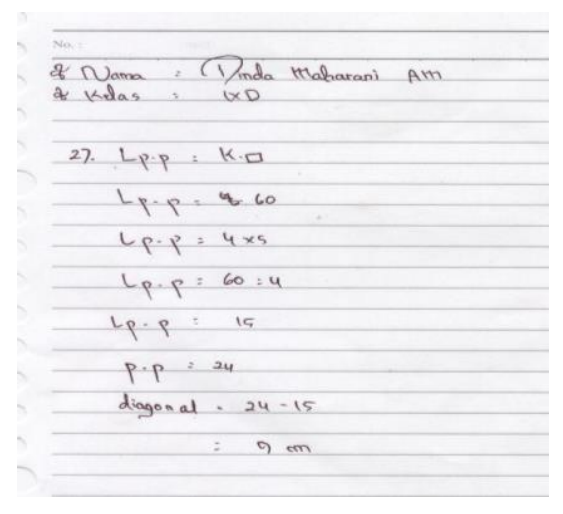

Figure 4. The Answer of Problem Number Two by Subject B

Students already slightly understand the intent of this matter, but students are less accurate in reading the questions. Students can not determine the length of the diagonal rectangle using the Pythagorean formula. Here is a recent interview about the work number 2:
Researcher : "Do you know what the meaning of problem number 2?"
Subject B : "Kind of mam.."
Researcher : "What do you mean?"
Subject B : "The area of rectangle is the same as the circumstance of square mam"
Researcher : "Which area of rectangle?"
Subject B : "Length time width mam"
Researcher : "yes right...then what's the circumstance formula of square?"

Subject B : "4 times the length of it side mam" 


\begin{tabular}{|c|c|c|}
\hline Researcher & & "Then your answer is 15 , how come?" \\
\hline Subject B & . & $\begin{array}{l}\text { "The area of rectangle is the same as the area of square } \\
\text { Whereas the circumstance of square is } 4 \mathrm{x} \text { its side, then the } \\
\text { area of the rectangle is } 60: 4=15 \text { mam..." }\end{array}$ \\
\hline Researcher & : & $\begin{array}{l}\text { "Please reread the question whether } 60 \mathrm{~cm} \text { is the } \\
\text { circumstance of square of the length side of square." }\end{array}$ \\
\hline Subject B & & "(she reread then smiled) The length of its side mam." \\
\hline Researcher & & $\begin{array}{l}\text { "If it's the length side, so what is the circumstance of the } \\
\text { square?" }\end{array}$ \\
\hline Subject B & $\cdot$ & "4 x $60=240$ mam. My previous answer is wrong." \\
\hline Researcher & : & $\begin{array}{l}\text { "Then if the circumstance is } 240 \text {, what is the area of the } \\
\text { rectangle?" }\end{array}$ \\
\hline Subject B & 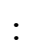 & "240 as well mam because it's the same" \\
\hline Researcher & : & $\begin{array}{l}\text { "The area is } 240 \text {, whereas the length of the rectangle is } 24, \\
\text { then what's the length, Din?" }\end{array}$ \\
\hline Subject B & : & "The width is $240: 24=10 \mathrm{~cm}$ mam.." \\
\hline Researcher & : & $\begin{array}{l}\text { "If you already find the length and the width, how's the } \\
\text { diagonal?" }\end{array}$ \\
\hline Subject B & : & $\begin{array}{l}\text { "(while drawing) The diagonal can be found by finding the } \\
\text { length of hypotenuse using Pythagoras formula mam." }\end{array}$ \\
\hline Researcher & : & "Then why did you answer $24-15$ ?" \\
\hline Subject B & & $\begin{array}{l}\text { "I just guessing mam since I have a problem with long } \\
\text { sentences (smiled)." }\end{array}$ \\
\hline
\end{tabular}

Based on the interview, the students had a little understanding of the intent of the story about these two numbers, the students also know about the formula for the area around the rectangle and square. Students just less conscientious in reading the questions, so students were wrong in finding the long side of a square. Whereas, the intention of this matter is seeking square around a known length of its side. In addition, students also do not understand about which one is diagonal rectangle, so the Pythagorean formula in determining the length of the diagonal can not be applied.

From the results of tests and interviews, the student is still confused in the drawing of the wind direction. Students also can not put the known distance to the direction of the ship running. In addition, students are still less careful in reading about the story so that students easily confused with intent matter. Students' understanding of the plane material is still less, mainly square and rectangular. This is apparent in interviews with students showed that students were still confused where the diagonal rectangle. According Maricica (2015), the results obtained indicate that the selection of the content can encourage and develop students' critical thinking. Meanwhile, according to Satoto (2012), based on the analysis of the results Researcheran that students in understanding the 
mistakes made by 4 Subject matter Researcheran. The reason is because the illustrations / wrong thinking.

\section{Answer of Subject C}

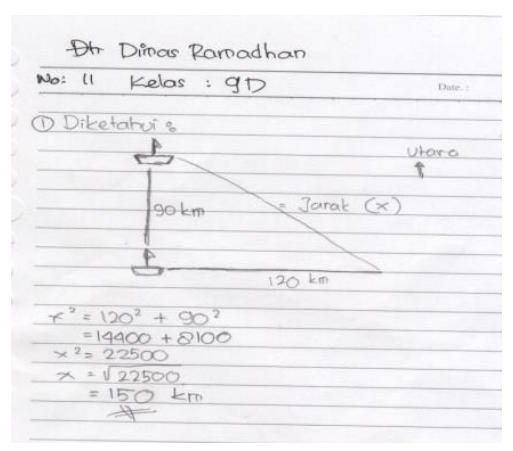

Figure 5. The Answer of Problem Number One by Subject C

Figure 5 shows the answer number 1 by the subject $C$. It can be seen that student answers correctly. Steps students work on the problems of this story first number is correct based on the expected answer, just that there lacked a bit of sign \pm . Students answer $\mathrm{x}^{\wedge} 2=$ $225000 \Leftrightarrow \mathrm{x}=\sqrt{ }(225000)(\Leftrightarrow) \mathrm{x}=150$. Supposedly $\mathrm{x}= \pm \sqrt{ } 225000 \Leftrightarrow \mathrm{x}= \pm 150$. The answer of the students should $\quad \mathrm{x}=150$ not $\mathrm{x}=150 \mathrm{~km}$, the unit $\mathrm{km}$ is raised by using "so".

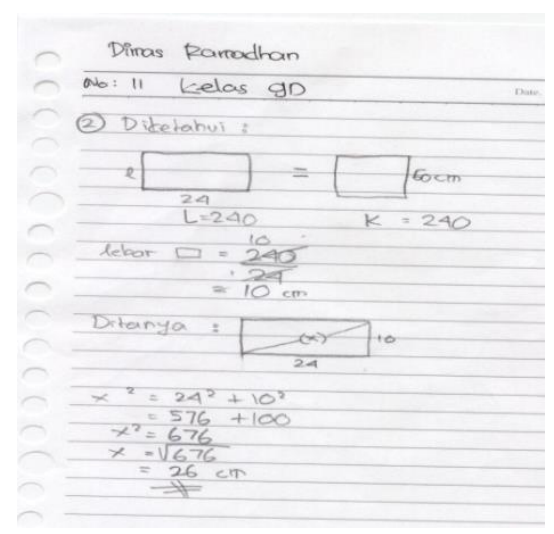

Figure 6. The Answer of Problem Number Two by Subject C

In Figure 6 Students are able to understand the intent and purpose of the question number 2. Students can determine the width of the rectangle before determining the diagonal length of the rectangle using the Pythagorean formula, but there is a shortage with \pm sign as Question 1 is student responsibility. Students' answer should have $\mathrm{x}=26$, instead of $\mathrm{x}=26 \mathrm{~cm}$, the unit $\mathrm{cm}$ raised by using "finished".

From the results of the students' answers, it seems that students' understanding of the subject matter of the story based problem on Pythagoras already apparent. However, Researcher wanted to make sure students have a good analysis. To the authors conducted a short interview related to number 2 . 


\begin{abstract}
Researcher : "Related to number 2, you did it well, but I still find some a little mistake."

Subject C : "Which one mam? I thought everything is right."

Researcher : "Your answer is $x^{2}=676 \Leftrightarrow x=\sqrt{676} \Leftrightarrow x=26$, but supposed $x^{2}=676 \Leftrightarrow x= \pm \sqrt{676} \Leftrightarrow x= \pm 26$."

Subject C : "Yes mam, I forgot.."

Researcher : "Then if the answer is $x= \pm 26$, why do you take $\mathrm{x}=26$, instead of $x=-26$ ?

Subject C : "Since it is the length of diagonal, $-26 \mathrm{~cm}$ is impossible to become as length side mam.."

From the excerpts of the interview above, students are able to understand the material Pythagoras, changing the word problems into mathematical models, and students also remember the previous material such as determining the area of a rectangle, a square circumference, and the direction of the wind. Only students are less in changing the $\mathrm{x}^{\wedge} 2$ $=676(\Leftrightarrow) \mathrm{x}=\sqrt{ } 676(\Leftrightarrow) \mathrm{x}=26$, which is supposed to be true is $\mathrm{x}^{\wedge} 2=676(\Leftrightarrow) \mathrm{x}= \pm$ $\sqrt{676}(\Leftrightarrow) \mathrm{x}= \pm 26$. And the student leave should the unit of length on the answer-not when the final calculation, but provides the unit of length on the time of conclusion.
\end{abstract}

A highly capable students already knew about the material Pythagoras, ranging from changing the word problems into mathematical models, determining the direction of the wind, determine the area of a rectangle, square circumference. Only students are still lacking in the calculation. It is seen in the students' answers, $x^{\wedge} 2=676(\Leftrightarrow) \mathrm{x}=\sqrt{676}$ $(\Leftrightarrow) \mathrm{x}=26$, which supposedly is $\mathrm{x}^{\wedge} 2=676(\Leftrightarrow) \mathrm{x}= \pm \sqrt{ } 676(\Leftrightarrow) \mathrm{x}= \pm 26$. As well as giving students a unit of length not when the final results dariperhitungan but give the length unit at the time of the conclusion by using the word "so".

\title{
$\underline{\text { Alternatif Solution }}$
}

The difficulty of the author may provide alternative solutions, among others:

1. Students in the category of low ability

Alternative solutions for students in low ability class is to give students an understanding of the material concept to Pythagoras, provide insight to students about Pythagoras matter in the form of word problems. This was done by teaching students to read the sentences in question carefully so that students understand which direction and purpose of the question, strengthens back on material already past, such as materials of rectangle and square. Additionally, reaffirm on determining the direction of the wind in the picture, giving the exercises on the Pythagorean so that students know and understand about the use of the Pythagorean formula instead of by rote. This is in line with Mulyadi (2015) who argued that teachers should be more emphasis on steps to resolve because many students did not know the concept so that the need for reviewing the material prasarat and increase understanding of each of the steps in solving problems by extending the exercises, Meanwhile, according to Yuwono (2016), an alternative solution is for students who have difficulty understanding the concepts and definitions is to apply the learning according to the Van Hiele theory, because in the 
learning stages are already terurutkan systematically, so that teachers can understand students' achievement.

Researcher thinks that by putting various forms about the Pythagorean especially about the story it will minimize errors for students because students are used to work on the problems. One of the goals listed in the mathematics learning Permendiknas number 22 of 2006 for SMP is solving problems that include the ability to understand the problem, devised a mathematical model, solve the model and interpret the obtained solution. In accordance with the purpose of learning mathematics then be given exercises related to solving problems in everyday life on the topic of Pythagoras thus students will get used to understanding about Pythagoras. While Seyitoglu, et al (2011) suggested that teachers use to teach concepts of mathematics history of mathematics. Thus, the instruction and mathematical concepts would be more meaningful for students. From the observations, the students experienced difficulties in receiving the lesson that teachers are expected to do better planning again.

2. Students in the category of moderate ability

Alternative solutions for students in the category of moderate ability is to provide understanding of the concept of matter, giving about - exercises in the form of word problems to students so that students understand more about the meaning of the sentence - the sentence in word problems, strengthens back on material already past, like material of rectangle and square and about determining the direction of the wind in the picture. This is evident in interviews with Subject B at about problem number 1. Subject B had difficulty in determining the direction of the wind that is where the west, east, north, and south in the image. According Nurussafa'at (2016), alternative solutions to operational errors that teachers continuously improve numeracy skills of students, teachers should math errors themes further enhance the mastery of the material to the students.

3. Students in the category of high capability

Alternative remedies for high ability students in a category is to provide practice problems - problems that students are more rapid and precise work on the problems, especially about the story of the Pythagorean theorem. As stated by Hidayat (2013) that students should be more caring, careful and pay attention in math learning materials and also improve numeracy skills with emphasis on exercises.

\section{Conclusion}

The results of this study indicate that the difficulties experienced by students in low skill category is the difficulty in determining the drawing wind direction, understanding the language, that understand the intent of the story about the difficulty in making a mathematical model as well as the difficulties experienced by students in its calculation. Difficulties category abilities was the difficulty in determining an image direction of the wind, trouble understanding the language, that understand the intent of the word problems, and difficulty in making models of student categories of mathematics. On high ability no problem in doing a good question number 1 or number 2 , only any student less add \pm sign in the answer and the unit of length is not included in the final calculation of unit length but written in the final conclusions. 
Alternative solutions for students in the category of low ability is to provide understanding of the concept to the students about the material Pythagoras, provide insight to students about about Pythagoras in the form of word problems, strengthen the back of the material that is already past, such as materials in the wake of a flat rectangle and square. Additionally, reaffirm on determining the direction of the wind in the picture, and give the exercises on the Pythagorean so that students know and understand about the use of the Pythagorean formula instead of by rote saja.Cara overcome difficulties to the students on the category of being is the ability to provide an understanding of the concept material, giving about shaped exercises about the story to the students so that students understand more about the meaning of the sentence about the story, strengthens back on material already past, such as materials in the wake of a flat rectangle and square. Additionally, reaffirm on determining the direction of the wind at gambar.Alternatif problem solving in students of high ability class is to provide practice problems that students are more rapid and precise work on the problems, especially about the story of the Pythagorean theorem.

\section{References}

Abdurrahman, Mulyono. (2012). Anak Berkesulitan Belajar. Rineka Cipta: Jakarta.

Agus, Nuniek Avianti. (2008). Mudab Belajar Matematika 2 untuk Kelas VII Sekolah Menengah Pertama/Madrasah Tsanawijah. Jakarta: Pusat Perbukuan Departemen Pendidikan Nasional.

Budiyono. (2008). Kesalahan Mengerjakan Soal Cerita dalam Pembelajaran Matematika. Paedogogia, Jurnal Researcheran Pendidikan, 11(1). Diakses dari http://jurnal.fkip.uns.ac.id/index.php/paedagogia/article.view/95.

Hidayat, B.R. (2013). Analisis Kesalahan Siswa Dalam Menyelesaikan Soal Pada Materi Ruang Dimensi Tiga Ditinjau Dari Gaya Kognitif Siswa (Researcheran dilakukan di SMAN 7 Surakarta Kelas X Tahun Ajaran 2011/2012), Jurnal Pendidikan Matematika Solusi UNS, Vol.1, No.1, 39-46.

Maricia, S. (2015). Developing Critical Thinking in Elementary Mathematics Education through a Suitable Selection of Content and Overall Student Performance, Procedia Social and Behavioral Sciences, 180, 653-659.

Mulyadi. (2015). Analisis Kesalahan Dalam Menyelesaikan Soal Cerita Pada Materi Luas Permukaan Bangun Ruang Berdasarkan Newman' S Error Analysis ( Nea ) Ditinjau Dari Kemampuan Spasial. Jurnal Elektronik Pembelajaran Matematika UNS, 3(4), 370-382.

Nurussafa'at, F.A. (2016). Analisis Kesalahan Siswa Dalam Menyelesaikan Soal Cerita Pada Materi Volume Prisma Dengan Fong's Shcematic Model For Error Analysis Ditinjau Dari Gaya Kognitif Siswa, Jurnal Elektronik Pembelajaran Matematika UNS, Vol.4, No.2, 174-187.

Permendiknas no 22 Tahun 2006.

Priyanto, A., \&Trapsilasiwi, D. (2015). Analisis Kesalahan Siswa dalam Menyelesaikan Soal Cerita Matematika Pokok Bahasan Teorema Pythagoras Berdasarkan Kategori Kesalahan Newman di Kelas VIII A SMP Negeri 10 Jember (Analysis of 8th Grade Junior High School 10 Jember Solving Math Story Problem of Pythagorean Theorem Based on Newman Error Category ), 1-5. 
Rahardjo, S.(2016). Analisis Kemampuan Koneksi Matematis Siswa Kelas VIII pada Materi Teorema Pythagoras: Prosiding Konferensi Nasional Researcheran Matematika dan Pembelajaran (KNPMP I), Diselenggarakan oleh Program Studi Pendidikan Matematika, UMS, 12 Maret 2016 (hal. 377-384).

Satoto, S. (2012). Analisis Kesalahan Hasil Belajar Siswa Dalam Menyelesaikan Soal Dengan Prosedur Newman. Unnes Journal of Mathematics Education, 1(2).

Seyitoglu, dkk. (2011). Students' views About Activities Developed on The History of Pythagoras' theorem, Procedia Social and Behavioral Sciences, 15, 882-886.

Yuwono, M.R. (2016). Analisis Kesulitan Belajar Siswa Kelas VII SMP Dalam Menyelesaikan Soal Materi Segitiga dan Alternatif Pemecahannya. Majalab Ilmiah Uinversitas Widya Dharma Klaten, No.95, 14-25. 